\title{
Toward Pedagogical Turnings
}

\section{Eric Detweiler}

The author is an assistant professor in the Department of English at Middle Tennessee State University. A version of the essay was presented at the 2017 MLA Annual Convention in Philadelphia.
IT WAS office hours, the middle of the semester. I'd assigned students in one of my courses - a general education literature course about banned and challenged books - a short, one-off imitation exercise. They had to write a dialogue imitating the voices of two people who appeared in a book they'd just read: what would those two say to each other had things unfolded differently at one point in the book? The assignment was based on a classical rhetorical exercise called ethopoeia, which was often assigned as part of a series of exercises called the progymnasmata and asked students to respond to prompts like these: "What words would Niobe say when her children lie dead?" "What words would a money-loving coward say upon finding a golden sword?" (Gibson 380-83, 406-07). As the first example suggests, students often imitated the voices of women in the midst or wake of trauma. Given that classical, medieval, and Renaissance classrooms were predominantly male, such imitations raise troubling issues: even if the exercise cultivated a "habit of alterity" in male students (Enterline 25), to what extent did it result in the appropriation of women's voices and experiences in the name of male students' pursuit of rhetorical mastery and cultural capital (Woods)? To what extent did such exercises reinforce stereotypical conceptions of women as quintessentially pathetic figures?

As a way of interrupting the problems of mastery and appropriation that can attend ethopoeia, I tried to position the assignment as an exercise in "unmastery." I hoped students' close encounters with the voices they imitated would attune them to the rhetorical and ethical limits of speaking for and as others. In the assignment prompt, I emphasized students' responsibility to these voices. In the class discussion on the day the assignments were due, I asked what gaps and cracks the exercise caused my students to notice in their understanding of the book and its characters. For both me and my students, it was a challenging rhetorical and ethical task. ${ }^{1}$

Anyway, it was office hours and in walked a student. She said she wasn't sure she could complete the exercise. It wasn't that she didn't understand the prompt or hadn't left herself enough time to write. She simply felt that writing the dialogue would violate the book's narrative and the writer's experiences (it was a memoir, not a novel). Faced with the task at hand, the student felt that the best path was to reject that task. To her mind, to write the exercise meant infringing on something sacrosanct.

In retrospect, hers might have been the best possible response to the assignment. At the time, I began cycling through a list of practical concerns: If I let her resistance stand, how would I grade it? Would this open the door to other students' using flimsier excuses to skip out on writing assignments? Was it fair to let her take a pass and still expect the rest of my students to turn in the exercise as assigned? Then again, wasn't our conversation, which probably took more time than some other students put into composing their imitations, evidence that she wasn't taking a pass at all? As one part of me responded to her concerns, another part felt knocked back into myself,

(C) Eric Detweiler

CrossRef DOI 10.1632/ade.155.52 
Toward Pedagogical

Turnings

Eric Detweiler fuzzily aware that these issues were calling me to rethink the principles and assumptions underlying the assignment. A part of me, in other words, began theorizing.

This piece emerged from a simple question-perhaps even too simple a question: what if, instead of naming our pedagogies after our theories, we named our theories after our pedagogies? But before jumping into that question and what I mean by theory, let me offer a quick piece of metacommentary, the significance of which will become more obvious as this piece unfolds: this paragraph and most of this section were not present in my first draft. In that draft, I took the meaning of theory for granted. However, a reviewer's helpful comments convinced me to situate my use of the term theory - more specifically, why I claimed the pedagogical encounter described above led me to theorize rather than, say, think or reflect.

Theorizing, thinking, and reflecting share some common territory. In The Life of the Mind, Hannah Arendt discusses the etymology of theory as part of her investigation into thinking. Drawing on "a parable attributed to Pythagoras" in which life is imagined as a festival attended by lowly participants and lofty spectators, Arendt observes:

From the Greek word for spectators, theatai, the later philosophical term "theory" was derived, and the word "theoretical" until a few hundred years ago meant "contemplating," looking upon something from the outside, from a position implying a view that is hidden from those who take part in the spectacle and actualize it. (93)

Arendt goes on to tie the supremacy Pythagoras granted to theorrein back to theos and "the Greek notion of the divine" (130). As spectator and quasi-divinity, the Pythagorean theorist contemplated the action from a safe, thoughtful distance.

In The Craftsman, Richard Sennett recalls a conversation that he had with Arendt in the wake of the Cuban Missile Crisis—a conversation about the relation between theory and practice. Sennett writes:

[I]n [Arendt's] view, we human beings live in two dimensions. In one we make things; in this condition we are amoral, absorbed in a task. We also harbor another, higher way of life in which we stop producing and start discussing and judging together. ... This division seems to me false because it slights the practical man or woman at work.

$(6-7)^{2}$

Sennett differentiates his view from Arendt's by invoking another Greek parable—not Pythagoras's festival, but Pandora's box. As Sennett puts it, Arendt's perspective blames the opening of Pandora's box on unthinking practitioners who, absorbed in the task of making for its own sake and isolated from public deliberation about what they are making and why, create things like the atomic bomb. While he does not downplay the horrors wrought by nuclear weapons or the terror of the Cuban Missile Crisis, Sennett argues that we must acknowledge, contra Arendt, that "thinking and feeling are contained within the process of making" and that "[t]he contents of Pandora's box can indeed be made less fearsome ... if only we better understand the making of things" $(7,8)$. Sennett pursues such understanding and in so doing calls into question the "fault lines" that history has installed between pairs like "practice and theory" (10).

But even theory itself has fault lines. For example, in Persuasion, Reflection, Judgment, Rodolphe Gasché elaborates on "a difference between two kinds of the 
Toward Pedagogical

Turnings

Eric Detweiler theoretical" traced out in Martin Heidegger's early work (82). Gasché differentiates "'radical theoretization,' which is grounded in a process of un-living" and which Heidegger associated with the presumed objectivity of the "theoretical sciences," from a "theoretical' attitude that characterizes its object ... in a sense of theorein that lets what is looked at give itself so that it can be lived [er-lebt], and, by being lived, experienced" (83). In other words, the second sense of "theoretical," while not strictly practical—and, Gasché notes, "atheoretical" in some senses of the word - maintains "a relation to the order of life" (84). For Gasché, this second kind of theory, derived from the Greek notion of theoria, "is an acting-thinking more originary than the classical theory/praxis divide" (69). And while Heidegger renders theoria as Besinnung, a German word often translated as "reflection," Gasché points out that he does so precisely "to avoid the subjectivist, metaphysical connotations of the Latin term 'reflectio"' (70). That is, while the second kind of theory described by Gasché challenges simple distinctions between theory and practice, it also highlights a distinction between one sense of theory and a certain kind of reflection.

Those three terms-theory, practice, and reflection-are also resituated in Casey Boyle's recent article "Writing and Rhetoric and/as Posthuman Practice," and here we are nearly back to the question at hand. Responding to the 2011 Framework for Success in Postsecondary Writing, Boyle questions the value that scholars and teachers of rhetoric and writing often attach to metacognition and the related concept of reflection. "If," he writes, "writing and writers are codependent with things and all sorts of others, then metacognition and reflective practice ... have the potential to become bad habits, since each reflective exercise persuades a writer to separate herself from all those things with which she is codependent" (534). Boyle repositions rhetoric as a "posthuman practice" that "unfolds not through the traditional conception of rhetoric as critical reflection about an object but as an ongoing series of mediated encounters" (535). He performs this reconception as he argues for it: his article unfolds as a "serial arrangement ... less oriented to the coherent letter [i.e., epistle] and more toward the overwhelming archive or database... I marshal an abundance of sources that perform similar work without being reflective on one another" (547). While Boyle deemphasizes reflection, he does not dismiss theory. Rather, he weaves theory and practice together: "practice is theoretical but does not claim privileged insight. Theory is a practice; at the very least, it is a practice of theory" (542). Theory and practice are not identical, but neither are they discrete. They are, as Boyle puts it, continuous.

In a sense, my project orbits Boyle's, and that is one reason I use theory rather than reflection or thinking. Reflection suggests a degree of separation not only from one's object of study and the real-time vagaries of practice but also from oneself. That is, when I look at my reflection in the mirror, I see myself from a distance and am thus able to notice things I would otherwise miss. I gaze upon myself in a way that mirrors the Pythagorean theorist gazing upon the spectacle. In short, reflection suggests a degree of spatial, temporal, and even existential distance that is not what I'm after. I'm interested in theory because it is practice's bandmate. But while Boyle draws on Andrew Pickering to position posthuman practice as a sort of "tuning" - that is, the entangled, reciprocal working together of people and things that can offer 
Toward Pedagogical

Turnings

Eric Detweiler "another materially informed way of seeing (theoria) or another way of being in the world" (542) - I am interested in theory as an "untuning" that emerges from or is coextensive with moments in which my habitual practices become untenable. These are not moments of serene, detached thoughtfulness, like reflectio or Pythagorean spectatorship. They are moments in which the demands of others, be they human or non-, call me to theorize. They are moments that unfold not above the fray but in it. While Boyle tunes into practice and adapts a database-inflected style of writing, I'm interested in what happens when practice generates feedback (meaning uncontrollable noise, not orderly response) so overwhelming that I have no choice but to theorize. Moreover, I'm interested in what writing styles might be called for if we approach theory as practice's momentary, codependent interruption. ${ }^{3}$

To return to my earlier question with this sense of theory in mind, what if, instead of naming our pedagogies after our theories, we named our theories after our pedagogies? I ask this question as a rhetorician. In a great deal of pedagogically focused rhetoric and writing scholarship, theory is articulated before pedagogical practices. Take, for instance, James A. Berlin's Rhetoric and Reality, a remarkable book that just turned thirty but continues to influence how rhetoric and writing scholars theorize and taxonomize pedagogies. Berlin begins his book by outlining "the major rhetorical theories" that influenced twentieth-century writing pedagogies (6). He argues that each of these theories, when deployed by teachers, "provid[es] students with guidance in seeing and structuring their experience." The theories we "call upon in teaching writing" matter because they have "important implications for the behavior of our students" (7). In the decades since Rhetoric and Reality was published, rhetoric and writing scholars have made rich use of it, adding to and challenging Berlin's taxonomy of rhetorical theories and the pedagogies they inspire. But when it comes to the structure of scholarly articles and monographs, members of the discipline have generally reenacted the way Berlin conceptualizes and performs the relation between theory and pedagogy: theory comes first, its explication a necessary prerequisite to describing or enacting a pedagogy. We name or identify a theory, then we derive a pedagogy from it. My question emerges from a concern that, even if our attention to theory is meant to ensure well-founded pedagogical practices, the priority we grant it leaves pedagogy a second-order, if still immensely pressing, matter.

Gerald Graff addressed related questions about the theory-practice relation in 1994's “The Pedagogical Turn." In that frequently cited piece, Graff describes two kinds of pedagogical turns. The first is disciplinary: Graff predicted a shift away from the "notoriously counter-pedagogical" brands of literary theory that dominated the early nineties. His vision of the field's future involved a "significant redirection of theoretical attention to issues of education and pedagogy" (65). Structurally, such a pedagogical turn would resemble other general spikes in interest and shifts in emphasis that affected English studies in recent decades: the linguistic turn, the political turn, the ethical turn.

But Graff's prediction didn't really apply to rhetoric. As Berlin's book suggests, rhetoric has long been a pedagogically oriented field (Hauser; Walker) — so much so, in fact, that the early nineties saw some rhetoric scholars challenging the field's 
Toward Pedagogical

Turnings

Eric Detweiler "pedagogical imperative" and calling for less haste in spinning theory into pedagogical practice (Worsham, "Writing" 96; see also Vitanza 160). Theoretically inclined scholars worried that rushing to pedagogy risked taming theory and limiting rhetoric's expansive potential (Worsham, "Going Postal"). Such calls have continued in the decades since, and rhetoric's disciplinary scope has indeed expanded well beyond the classroom (Dobrin). Thus, when twenty-first-century rhetoric scholars say practice, they aren't necessarily talking about pedagogical practice. They might be proposing new approaches to workplace communication, activist engagement, or designing digital platforms.

Which brings me to the second pedagogical turn that Graff discusses: the "“___ in the classroom' formula" he claimed had "become the standard convention for theory books, signaling a new feeling that a theory has not been fully expounded until its implications for teaching are spelled out" (66). In other words, the books Graff refers to conclude by turning from theory to pedagogy.

Rhetoric's expanding scope has in some ways pushed against this convention. I'd wager that if you selected a random rhetoric monograph published in 1997, you'd more likely see this second kind of pedagogical turn, a "___ in the classroom" chapter, than if you selected a random one published in 2017. Yet if you broaden the terms a little, things start to look fairly familiar. While pedagogy is no longer the only form of practice on the table, rhetoric scholarship still tends to start with theory and then turn toward practice. Consider the subtitle of Deborah CoxwellTeague and Ronald F. Lunsford's First-Year Composition: From Theory to Practice; or Laurie Gries's Still Life with Rhetoric, in which a section entitled "A New Materialist Rhetorical Approach in Theory" precedes a section entitled "A New Materialist Rhetorical Approach in Practice"; or Douglas Eyman's Digital Rhetoric: Theory, Method, Practice, the final section of which "focuses on three main areas of digital rhetoric as practice" (112) — but only after separate sections devoted to theory and method.

That is, even in inventive rhetorical projects not especially or exclusively concerned with pedagogy, projects I admire greatly, many scholars continue to enact a sort of practical turn: practice follows theory, with theory as the foundation that must be in place before a practice can be built. I'm working with a fairly obvious construction metaphor. If you imagine scholarship as a building, it's easy to imagine theory as its foundation. You must make sure it's constructed carefully—no cracks and gaps-or anything you build on it will be less stable, more vulnerable to damage from outside forces and unforeseen circumstances. Then again, imagine if a rogue construction team roamed the country laying down solid foundations with no plans to build anything more. Most of us would probably write it off as odd, unproductive, a waste of resources. After all, a foundation isn't supposed to be an end in itself-the building is what justifies its existence. Metaphorically speaking, a practice is only as stable as the theory it's built on, and a theory is only as worthwhile as the practice that can be built on top of it.

In 1987's The Making of Knowledge in Composition, Stephen North offered a similar metaphor. North distinguishes between composition's practitioners and its researchers. As he puts it, "researchers make knowledge, practitioners apply it." He gives a particular name to the practices and traditions on which practitioners build: 
Toward Pedagogical

Turnings

Eric Detweiler lore. And that brings us back to construction. According to North, the "House of Lore" is a

rambling ... delightful old manse, wing branching off from wing, addition tacked to addition. ... Each generation of Practitioners inherits this pile from the one before, is ushered around some of what there is, and then, in its turn, adds on its own touches. Naturally, the structure is huge, sprawling. There are, after all, no provisions for tearing any of it down.

In 2014's After Pedagogy, Paul Lynch takes up North's metaphor. He sees it as gently condescending, reinforcing a divide between the rickety knowledge of practitioners and the sound, research-based knowledge of scholars (13-14). He glosses North like this: "Lore can disguise itself with the vestments of other methods, but such adornment serves only to confuse. Delightful though it may be, lore is not scholarship" (14). Lynch maps North's distinction between lore and method onto the more familiar distinction between practice and theory. Searching for a way to make respectful use of the knowledge of practitioners, he asks, "[C]an we make a method of lore?" (17). ${ }^{4}$ Drawing on John Dewey, who "reject[ed] the distinction between theory and practice as false" (19), Lynch proposes "experience" as a term that encapsulates both theory and practice, then spends much of the rest of his book trying to "resolve the dualisms that trouble our discipline" (68). ${ }^{5}$

As we have seen with Boyle's work, Lynch is not alone in rethinking rhetoric's and writing's conception of the theory-practice relation. In a similar vein, Jessica Enoch has recently explored and questioned ways in which "abductive" methods can "interanimate ... traditional methods" (41; cf. Dobrin and Jensen). In these cases, the line dividing practice from theory is blurred —or perhaps it's more accurate to say more connections are drawn between the two. But blurring, tightening, multiplying, or dividing the ties between theory and pedagogy and practice is not necessarily what I'm after. I'm interested in reordering the relation: not theory as practice or theory without practice but practice before theory. Before I make a final case for such a reversal, though, I need to add one more track into the mix: the recent hubbub around postcriticism, with particular reference to Rita Felski's The Limits of Critique.

Several theorists in both literature and rhetoric have grown weary of something called critique. Inspired particularly by Eve Kosofsky Sedgwick's "reparative reading" and the work of Bruno Latour, these theorists argue that critique has become too cynical and totalizing (in addition to Felski, see Grabill; King; Rivers). The problem isn't necessarily critique itself but the condescending attitude of the critic. As the argument goes, cynical forms of critique allow scholars to approach objects of study in ways that primarily confirm the critic's preexisting ideological assumptions (Felski 64). Felski characterizes the critic's main moves as digging down and standing back (52), both of which position critics as justifiably suspicious figures whose critical lenses allow them a more thoroughgoing view of the object they're studying. Digging down, they can reveal a novel's latent subconscious drives or contradictions. Standing back, they can see the bigger picture, revealing that another writer's sense of free will is an illusion. While she doesn't reject critique wholesale, Felski is tired of the cycle of self-perpetuating, self-justifying suspicion generated by particular 
Toward Pedagogical

Turnings

Eric Detweiler critical approaches. She proposes less cynical alternatives: taking seriously students' emotional and affective responses to literature (180-81), admitting the limits and vulnerabilities of our critical approaches (174).

While I am on board with a great number of Felski's claims, I would submit that rhetoric scholars have been doing such work for quite a while-work that pushes the limits of even Felski's more expansive approach to hermeneutics (175; in addition to the rhetorical projects cited in the previous paragraph, see Crowley on invention; Davis, "Addressing," on rhetoric's nonhermeneutic dimension). For the moment, though, my concern is the ease with which what Felski calls "critique" becomes, in the broader postcritical conversation, synonymous with theory. Many of literary studies' and rhetorical studies' dominant approaches can be glossed as both theoretical and critical. One can say feminist theory or feminist criticism and mean basically the same thing. Deconstruction, Marxism, psychoanalysis - with all these schools of thought, it's possible to append the modifier critical or theoretical in equal measure. I'm not saying these words or terms are synonymous-just that they often function that way. After all, Felski's skeptical critic can sound a lot like Pythagoras's spectating theorist.

But I want to argue that theory can be and do something different from critique. Both theory and critique can allow a scholar to observe from a distance, to comment haughtily on the world of practice. But I often end up theorizing not because I'm watching something, whether it's pedagogy or some other form of practice, from a distance. It's not a simple matter of standing back from what happens in the classroom. I often theorize because I'm knocked back by an unforeseen pedagogical event-which returns me to the narrative with which I began this piece. In that case as in so many others, theory emerged not as an attempt to prepare things before I taught but to make after-the-fact sense of an interruption in my usual practices. That's not to say the exercise wasn't the product of my own theoretical (including rhetorical, ethical, and affective) convictions. But as the student sat in my office, theory occurred not because I was standing back from pedagogical practice but because practice took me out. It emerged out of and as the experience of seeing part of my pedagogy collapse, and it continued as a halting effort at rebuilding-a collaborative effort that involved textbooks, students, writing exercises, and journal reviewers.

Yet as I've tried to show, when we put our pedagogical theories and practices out into the world as scholarly publications, theory generally comes first. Despite the challenging and innovative arguments that Felski puts forward in The Limits of Critique, she offers classroom applications for her postcritical vision only toward the end of the book (180). Though Lynch draws on Dewey to erase or redraw the lines between theory and practice, he still has to get his theoretical house in order first. Scholarship on grounded theory, when it comes to matters of form and structure, still tends to lay foundations before it builds practices on them. I would argue that this structure — the ongoing prevalence of Graff's " “___ in the classroom' formula" (which perhaps I should revise as the "theory in the __ formula)—contributes to the overconfidence many scholars associate with the field's reigning theoretical and critical approaches. It might suggest to graduate students, for instance, that practices and pedagogies are things one arrives at only after extensive theoretical inquiry. 
Toward Pedagogical

Turnings

Eric Detweiler
If that's the case, of course many of those entering the field will grant priority to and place their confidence in theory. In short, if we want to interrupt overconfident modes of theory, we should interrupt the convention of placing theory before practice in our scholarly publications. I am not calling for the end of theory, nor for a turn or return to isolated pedagogical anecdotes as a superior scholarly form. Rather, I am calling for pedagogical turnings: performative acknowledgments of the ways pedagogy drives theory inspired by pedagogy derived from theory. Not just as an anecdotal exigency in the opening pages of our projects (which, admittedly, is basically what I've done here), nor as the obligatory payoff in our closing pages, but as a kind of recursive, recurrent interruption in our theoretical endeavors. We need more interruptive ways of writing that show how pedagogy and theory can support and undermine each other and in the process demonstrate the intertwined nature of theorist and practitioner or teacher. Along the way, we might find ways of writing that offer more humble, fragile perspectives on how the work of theorizing unfolds.

In closing, then, let me return once more to my key question: what if, instead of naming our pedagogies after our theories, we named our theories after our pedagogies? Over the course of composing this piece, I've become uncertain about this question. It is not so much a matter of flipping the question but of articulating how theory and pedagogy — and perhaps practice more broadly defined — are constantly naming and renaming, interrupting and speaking to each other, again and again and yet again. And that, I would close by hesitantly arguing, is what I have attempted to demonstrate here.

\section{Notes}

1. For a different account of this exercise, see Detweiler.

2. Beyond his personal interactions with Arendt, Sennett's main source for his characterization of her perspective is her book The Human Condition. It is worth noting that The Life of the Mind, the primary work of Arendt's on which I draw here, is based on ideas and arguments she put forth well after The Human Condition and that her description of Pythagoras's spectator is not a straightforward defense of his point of view.

3. For other takes on interruption as a rhetorical phenomenon, see Rice 29; Davis, "Confessions."

4. Lynch's use of method suggests one possible challenge to my discussion of the relation between theory and pedagogy. Plenty of scholars-literacy scholars doing ethnographic studies, for instanceproceed inductively, deriving theoretical conclusions from their on-the-ground observation of literacy practices. This is a different approach from the more deductive movements of scholars who draw pedagogies and practices from theories. For scholars working in inductive modes, method and methodology often take the place of theory in more deductive work. That is, method and methodology provide the foundation or framework that structures and delimits the scholars' descriptions of their practices. While I am not calling for replacing deduction with induction, it's worth noting that induction paves a different path than the more deductive approaches I'm foregrounding here.

5. Lynch's remarkable book is one of the main inspirations for this piece. That book begins with the "Monday Morning Question”: “This theory (or idea, or philosophy) you're proposing is great and everything, but what am I supposed to do with it when the students show up on Monday morning?” (xi). Lynch responds with what he calls "the Tuesday Morning Question: what do we do on Tuesday morning with the experience of Monday morning?” (xviii). I'm interested in both the Monday Morning Question and the Tuesday Morning Question but also the Wednesday Morning Question, the Monday Afternoon Question, and the Lying Awake at 2:30 a.m. on a Saturday Night Question.

\section{Works Cited}

Arendt, Hannah. The Life of the Mind. Edited by Mary McCarthy, Harcourt, 1978. 


\section{Toward Pedagogical}

Turnings

Eric Detweiler
Berlin, James A. Rhetoric and Reality: Writing Instruction in American Colleges, 1900-1985. Southern Illinois UP, 1987.

Boyle, Casey. "Writing and Rhetoric and/as Posthuman Practice." College English, vol. 78, no. 6, 2016, pp. 532-54.

Coxwell-Teague, Deborah, and Ronald F. Lunsford, editors. First-Year Composition: From Theory to Practice. Parlor Press, 2014.

Crowley, Sharon. “Composition Is Not Rhetoric.” Enculturation, vol. 5, no. 1, 2003, enculturation.net/ 5_1/crowley.html.

Davis, Diane. "Addressing Alterity: Rhetoric, Hermeneutics, and the Nonappropriative Relation." Philosophy and Rhetoric, vol. 38, no. 3, 2005, pp. 191-212.

- "Confessions of an Anacoluthon: Avital Ronell on Writing, Technology, Pedagogy, Politics." $J A C$, vol. 20, no. 2, 2000, pp. 243-81.

Detweiler, Eric. "Imitating Bechdels in Banned Books and Novel Ideas: An Exercise in Rhetorical Unmastery." Approaches to Teaching Alison Bechdel's Fun Home, edited by Judith Gardiner, Modern Language Association, forthcoming.

Dobrin, Sidney I. Postcomposition. Southern Illinois UP, 2011.

Dobrin, Sidney I., and Kyle Jensen, editors. Abducting Writing Studies. Southern Illinois UP, 2017.

Enoch, Jessica. "Abductive Historiography: This Is a (Feminist) Test." Dobrin and Jensen, pp. 27-46.

Enterline, Lynn. Shakespeare's Schoolroom: Rhetoric, Discipline, Emotion. U of Pennsylvania P, 2012.

Eyman, Douglas. Digital Rhetoric: Theory, Method, Practice. U of Michigan P, 2015.

Felski, Rita. The Limits of Critique. U of Chicago P, 2015.

Gasché, Rodolphe. Persuasion, Reflection, Judgment. Indiana UP, 2017.

Gibson, Craig, translator. Libanius's Progymnasmata: Model Exercises in Greek Prose Composition and Rhetoric. Society of Biblical Literature, 2008.

Grabill, Jeff. "The Work of Rhetoric in the Common Places: An Essay on Rhetorical Methodology." JAC, vol. 34, nos. 1-2, 2014, pp. 247-67.

Graff, Gerald. "The Pedagogical Turn.” The Journal of the Midwest Modern Language Association, vol. 27, no. 1, 1994, pp. 65-69.

Gries, Laurie E. Still Life with Rhetoric: A New Materialist Approach for Visual Rhetorics. Utah State UP, 2015.

Hauser, Gerard. "Teaching Rhetoric; or, Why Rhetoric Isn't Just Another Kind of Philosophy or Literary Criticism.” Rhetoric Society Quarterly, vol. 34, no. 3, 2004, pp. 39-53.

King, Claire Sisco. Conference presentation. Theory for (a) Change. Rhetoric Society of America Conference, 29 May 2016, Hilton Atlanta.

Latour, Bruno. "Why Has Critique Run Out of Steam? From Matters of Fact to Matters of Concern." Critical Inquiry, vol. 30, 2004, pp. 225-48.

Lynch, Paul. After Pedagogy: The Experience of Teaching. National Council of Teachers of English, 2014.

North, Stephen M. The Making of Knowledge in Composition: Portrait of an Emerging Field. Heinemann, 1987.

Rice, Jeff. Craft Obsession: The Social Rhetorics of Beer. Southern Illinois UP, 2016.

Rivers, Nathaniel. "We Have Never Been Critical." Itineration: Cross-Disciplinary Studies in Rhetoric, Media, and Culture, 20 Oct. 2013, vimeo.com/77341863.

Sedgwick, Eve Kosofsky. "Paranoid Reading and Reparative Reading; or, You're So Paranoid You Probably Think This Essay Is about You." Touching Feeling: Affect, Pedagogy, Performativity, Duke UP, 2003, pp. 123-54.

Sennett, Richard. The Craftsman. Yale UP, 2009.

Vitanza, Victor J. "Three Countertheses; or, A Critical In(ter)vention into Composition Theories and Pedagogies." Contending with Words: Composition and Rhetoric in a Postmodern Age, edited by Patricia Harkin and John Schilb, Modern Language Association, 1991, pp. 139-72.

Walker, Jeffrey. The Genuine Teachers of This Art: Rhetorical Education in Antiquity. U of South Carolina P, 2011.

Woods, Marjorie Curry. "Boys Will Be Women: Musings on Classroom Nostalgia and the Chaucerian Audience(s)." Speaking Images: Essays in Honor of V. A. Kolve, edited by Robert F. Yeager et al., Pegasus, 2001, pp. 143-66.

Worsham, Lynn. "Going Postal: Pedagogic Violence and the Schooling of Emotion.” JAC, vol. 18, no. 2, 1998, pp. 213-45.

—_. "Writing against Writing: The Predicament of Écriture Féminine in Composition Studies." Contending with Words: Composition and Rhetoric in a Postmodern Age, edited by Patricia Harkin and John Schilb, Modern Language Association, 1991, pp. 82-104. 